\title{
INTERNATIONAL CRIMINAL LAW AFTER ROME: CONCERNS FROM A U.S. MILITARY PERSPECTIVE
}

\author{
WILLIAM K. LIETZAU*
}

\section{INTRODUCTION}

On July 17, 1998, a United Nations Convention room in Rome filled with cheers as the text for the Statute to Establish an International Criminal Court (the "ICC") was adopted by a vote of 120 to seven, with twenty-one abstentions. At times, it appeared that the cheers were as much to celebrate the defeat of the United States, which had demanded the vote, as they were to applaud the adoption of the text. While many have praised U.S. proposals and contributions to the ICC treaty, there are also numerous detractors of its refusal to join. No one argues that the absence of the United States from the community of ICC proponents is ideal, especially since the United States has consistently supported the concept of an ICC for many years, ${ }^{1}$ but the question remains as to whether this means the United States is wrong not to join the treaty.

Perhaps equally disturbing, the United States has received criticism for the broader foreign policy pattern that seems to be emerging in which it is increasingly isolated and maligned as a black sheep during multilateral negotiations. Frequently, this isolation appears to be associated with a conservative attitude on the part of the U.S. armed forces with respect to recent developments in the law of war. Only nine months prior to the vote on the ICC, the U.S. delegation to an international negotiation in Oslo walked out of the conference hall the day before voting for a treaty to ban landmines was scheduled, thus precluding the need to break consensus and demand a vote. In both instances, the Ottawa

Copyright (C) 2001 by William K. Lietzau

This article is also available at http://www.law.duke.edu/journals/64LCPLietzau.

* Lieutenant Colonel, USMC; Deputy Chief Judge and Atlantic Circuit Judge, Navy-Marine Corps Trial Judiciary; former Deputy Legal Counsel to the Chairman of the Joint Chiefs of Staff and member of the U.S. delegation to the ICC negotiations.

This article, in significant part, was previously published in the United States Air Force Academy's Journal of Legal Studies as One Road Away from Rome: Concerns Regarding the International Criminal Court, 9 U.S.A.F. ACAD. J. LEGAL STUD. 33 (1999). Special recognition should be given to Rear Admiral Michael F. Lohr, JAGC, USN, who, as Legal Counsel to the Chairman of the Joint Chiefs of Staff, contributed so much wisdom and leadership to the legal and policy debate discussed herein.

1. President Clinton, for example, gave public support for a permanent international criminal court on six occasions prior to the diplomatic conference in Rome. See David J. Scheffer, The United States and the International Criminal Court, 93 AM. J. INT'L L. 12, 13 (1999)(providing citation for each). 
Convention ${ }^{2}$ and the Rome Treaty, ${ }^{3}$ the United States was largely isolated internationally-opposed not only by historic "adversaries," but also by many of its closest traditional allies. ${ }^{4}$ Again, few would argue that these are happy circumstances, but does that mean the remedy is to capitulate and more readily join the majority in negotiations that produce results contrary to the interests of the United States?

The answer to both questions is no. The specific decision to remain outside the Rome Treaty as currently formulated is the right one, and so is the more general willingness of the United States to stand firm in the minority. The emerging multi-polar, post-Cold War negotiating dynamic may call for some policy adjustments, but capitulation is not the answer-neither in the decision regarding whether to sign the ICC Statute, nor as a broader negotiating posture in future fora.

The United States has stated that it has no present or future intention to sign the current formulation of the Rome Treaty. ${ }^{6}$ This is consistent with its posture throughout the ICC negotiation process. At the Rome Conference, the U.S. delegation clearly stated that it would be forced to oppose any treaty that

2. Convention on the Prohibition of the Use, Stockpiling, Production, and Transfer of AntiPersonnel Mines and on their Destruction, Sept. 8, 1997, 36 I.L.M. 1507 [hereinafter Ottawa Convention]. The United States was unsuccessful in its attempt to convince negotiating delegations to build provisions into the treaty that would allow for self-destructing/self-deactivating submunitions as part of a mixed anti-tank/anti-personnel mine package or to accommodate the situation requiring landmine use along the northern border of the Republic of Korea. See generally Andrew C.S. Efaw, The United States' Refusal to Ban Landmines: The Intersection Between Tactics, Strategy, Policy, and International Law, 159 MIL. L. REV. 87 (1999).

3. Rome Statute of the International Criminal Court, July 17, 1998, U.N. Doc. A/CONF. 183/9, reprinted in 37 I.L.M. 999 (1998)(as reissued by the U.N. Secretariat Legal Counsel after making technical modifications to the text adopted by the U.N. Diplomatic Conference of Plenipotentiaries on the Establishment of an International Criminal Court in Rome, Italy, June 15-July 17, 1998) [hereinafter "ICC Statute" or "Rome Treaty"].

4. The Ottawa Convention has been signed by all NATO allies except Turkey and the United States. Only China, Iraq, Israel, Libya, Qatar, and Yemen joined the United States in voting against the Rome Treaty. See Mark Fritz, Pentagon seeks funds for new type of land mine, L.A. TimES, Feb. 20, 1999, at A1; Marilyn Henry, Treaty to create Permanent International War Crimes Tribunal, JERUSALEM POST, July 19, 1998, at A1.

5. Recent developments in multilateral negotiations evince a possible shift from this unfortunate trend. For example, the United States was able to join a consensus regarding the text that emerged from the Diplomatic Conference on the Second Protocol to the Hague Convention for the Protection of Cultural Property in the Event of Armed Conflict. See generally Jan Hladik, Documents: Diplomatic Conference on the Second Protocol to the Hague Convention for the Protection of Cultural Property in the Event of Armed Conflict, The Hague, Netherlands (Mar. 15-26, 1999), 8 InT'L J. Cultural ProP. 526 (1999). Similarly, a compromise was reached in the Optional Protocol to the Convention on the Rights of the Child on Involvement of Children in Armed Conflict, recently approved by the General Assembly at U.N. Doc. A/54/L.84 (2000). Article 1 represents a compromise between those who wanted to proscribe all military activities, including recruitment, involving persons under eighteen, and those who recruit younger persons, with the following language: "State Parties shall take all feasible measures to ensure that members of their armed forces who have not attained the age of eighteen years do not take a direct part in hostilities."

6. See David J. Scheffer, Statement on the International Criminal Court, Remarks Before the 53rd Session of the U.N. General Assembly, in the Sixth Committee, USUN Press Release No. 179 (Oct. 21, 1998) [hereinafter Sixth Committee Statement] (available at http://www.state.gov/www/policy_remarks/ 1998/981021_scheffer_icc.html; Statement of the United States before the U.N. General Assembly (Dec. 8, 1998)(on file with the State Department)). 
claimed jurisdiction over non-party nationals. The ICC contemplated by a plain reading of the Rome Treaty is unacceptably flawed in this respect. So, too, is the "fast-track" treaty-making process that created it. As currently postured, neither text nor process deserve U.S. support.

\section{II}

\section{U.S. CONCERNS LEADING UP TO ROME}

Prior to the Rome negotiations, the U.S. military identified a number of substantive concerns with the draft treaty text. Foremost among these were the following: jurisdiction or the "trigger mechanism," definitions and elements of crimes, state cooperation obligations in light of national security requirements, and rules of evidence and procedure. These concerns stemmed from a belief that an ICC lacking appropriate checks and balances would be vulnerable to political manipulation and, in turn, would detract from the rule of law. Wellintentioned calls for more ready and unimpaired enforcement of the laws of war must be tempered and balanced by the human rights of an accused, a commitment to fairness, acknowledgment of legitimate national security interests, and respect for the rule of law itself. This sense of balance inspired U.S. positions in Rome and continues to be the centerpiece of current concerns.

With reference to jurisdiction, it was always envisaged that the ICC would complement national justice systems, not replace them. There are both practical reasons and profound concerns of principle that militate against an ICC role independent of the states that imbue it with authority. From a utilitarian perspective, there is a legitimate concern that an unconstrained jurisdiction would simply overwhelm the court. Also, the clearest current deterrent to widespread violation of the law is found in state domestic law and the disciplinary codes and judicial systems of the various armed forces. ${ }^{7}$ Nothing established by an ICC treaty should be allowed to undermine these most fundamental protections against abuses of basic human rights.

More importantly, the ICC was conceived to bring to justice individual perpetrators of the most heinous acts. It was not designed to be-and should not become-a means of addressing international security issues associated with state action since this undermines the structures in place to maintain international peace and security. In this regard, the court should not supplant highly developed national legal systems of states that have the right and duty to investigate and prosecute crimes within the jurisdiction of the ICC without the

7. The United States has consistently demonstrated a willingness to discipline its own. See, e.g., GEORGE S. PRUGH, LAW AT WAR: VIETNAM, 1964-1973, at 76-78 \& annex K at 154 (1975)(discussing war crimes prosecutions during the Vietnam conflict). For more recent prosecutions, see, e.g., United States v. McMonagle, 38 M.J. 53 (A.C.M.R. 1993) and United States v. Finsel, 33 M.J. 739 (A.C.M.R. 1991)(both cases involving prosecutions for, inter alia, shooting firearms into the air above Panama City), and United States v. Mowris, No. 68 (Fort Carson \& 4th Inf. Div (Mech) July 1, 1993), discussed in Mark S. Martins, Rules of Engagement for Land Forces: A Matter of Training, Not Lawyering, 143 MIL. L. REV. 1, 17-18 (1994)(negligent homicide conviction of U.S. Army Specialist for killing a Somali national). 
authority of the U.N. Security Council to do so. It was always assumed that the ICC treaty would ensure that the ICC would not become a vehicle for interfering with responsibilities of states, especially those with the demonstrated ability to investigate and discipline their citizens and service members who are alleged to have violated the law of armed conflict.

A number of jurisdictional formulations were proffered both before and during the Rome negotiations. None met the United States' requirements of adequate protection for U.S. forces, appropriate recognition of state sovereignty, and sufficient acknowledgment of the Security Council's role. Particularly troublesome were initiatives to empower the court with true universal jurisdiction. Such jurisdiction, surely asserted in the practice of most governments of the world, is overly expansive when associated with an independent, and relatively unaccountable, institution. Under such an arrangement, the court would have jurisdiction over individuals regardless of whether any relevant state had consented to that jurisdiction. ${ }^{8}$

In considering definitions and elements of crimes, it was deemed critical that the court be limited to dealing with only those offenses that were universally recognized as crimes under international law. ${ }^{9}$ The ICC is an inappropriate vehicle for legislating substantive international criminal norms or for advancing definitions of crimes that are themselves politically controversial (for example, the use of nuclear weapons or the crime of aggression). The United States determined that the list of crimes should be limited to genocide, war crimes, and crimes against humanity, and that elements of proof for each offense should be specifically enumerated in the treaty text.

The U.S. proposal for elements of proof is a useful case in point regarding the utility of various checks and balances. The exposition of elements of proof is a necessary component of a lawful criminal justice system. While understanding that different criminal justice systems function with different levels of specificity and precision, in order for the ICC treaty to enjoy widespread acceptance and function appropriately, the court must have standards of due process that are at least as rigorous as those of its member states. Considering the seriousness of the crimes and penalties within the jurisdiction of the court, specificity as to criminal elements becomes an issue of fundamental fairness and the protection of human rights. The articulation of elements gives meaning to the principle of legality, nullum crimen sine lege, and those elements serve as a necessary guide to prosecutors as to what must be proved and to defense counsel as

8. Though the most extreme versions of this proposal were ultimately rejected, in some circumstances the statute authorizes jurisdiction over individuals without the consent of any state that might take responsibility for the prosecution. That is, if jurisdiction is based on territoriality, the state of territory is responsible, and may be held accountable, for the conduct and fairness of the prosecution. When jurisdictional authority is delegated via the ICC regime, responsibility can be shirked and the accountability of the Westphalian system is lost.

9. Customary status was generally the touchstone for determining which offenses would be included in the statute. See, e.g., 1 Report of the Preparatory Committee on the Establishment of an International Criminal Court, U.N. GAOR, 51st Sess., Supp. No. 22, at 16, U.N. Doc. A/51/22 (1996)(confirming understanding that the statute is not intended to create new substantive law). 
to what must be defended against. Equally important to the United States are concerns that ICC judges - in the absence of elements-might apply their varied and not always pertinent experiences to shape the law in unforeseen ways. Such judicial activism is improper for any body not directly accountable to the people, ${ }^{10}$ and it is especially inappropriate for a criminal court. An institution that purports to enforce the law must itself be bound by it. ${ }^{11}$

Regarding information deemed vital to a state's national security interests, the draft statute naturally encouraged state cooperation with court requests for documents and evidence. What was not clear at the beginning of the Rome negotiation was where the final decision lay as to what documents, witnesses, or other evidence must be provided to the court, even over a state's objection based on national security objections. The United States strongly believed that a state's legitimate right to assert national security reasons for refusing to surrender sensitive material should not be subject to a contravening ICC order. While a state would normally not spurn cooperation with an appropriately constituted ICC, at the same time, the ICC should not be empowered to overrule state decisions regarding national security matters. ICC judges would not be selected based on their expertise in the national security matters of states they may never have even visited. The United States thus considered a strong national security exception to be an essential component of the statute's state cooperation regime.

Finally, the United States was concerned with the proper balance to be struck regarding certain substantive principles of criminal law. For example, it would be inappropriate for obedience to lawful orders to serve as a defense for war crimes, but a soldier should not be held liable for obeying an apparently lawful order. ${ }^{12}$ Similarly, as rules of evidence and procedure represent the essential working mechanisms of any criminal justice system, the United States determined that clearly articulated rules of evidence and procedure, specifically set forth in the statute, were essential to a court worthy of support. Such rules help safeguard fundamental principles of fairness and ensure that the fundamental rights of potential defendants are not left to the whims of international judges from a variety of legal traditions.

10. Though beyond the purview of this article, it is worth noting that courts in democratic societies are always at least indirectly accountable to the body politic over whose members it wields authority. Such is not the case regarding ICC jurisdiction over nonparty nationals.

11. The requirement for elements of crimes was incorporated in Articles 9 and 21 of the statute. For a more detailed discussion of the U.S. proposal for elements of crimes, including a copy of the text currently being negotiated by the Preparatory Commission, see William K. Lietzau, Checks and Balances and Elements of Proof: Structural Pillars for an International Criminal Court, 32 CORNELL INT'L L.J. 477 (1999).

12. The ICC's antecedents, the Nuremberg Charter and the statutes establishing the International Criminal Tribunals for the former Yugoslavia and for Rwanda, all contained simplistic statements that obedience to orders was not a defense. Such an unsophisticated summarization of customary law was seen as inappropriate for a permanent court, and, at U.S. insistence, this provision was refined during ICC negotiations. See Charles Garraway, Superior Orders and the International Criminal Court: Justice Delivered or Justice Denied, 81 INT'L. REV. 785 (1999). 
III

\section{RESUlTS OF THE ROME NEGOTIATIONS}

The treaty text that resulted from the Rome negotiations met many of the United States' concerns. There is a generally acceptable list of crimes within the Court's subject matter jurisdiction (aggression stands out as a notable exception)..$^{13}$ The definitions of war crimes and crimes against humanity found in the statute generally comport with customary principles of international law. The Rome Conference accepted the proposal that there should be elements of proof and rules of evidence and procedure set in place by the assembly of states parties and not set ex post facto by the judges. ${ }^{14}$ A Preparatory Commission ("PrepCom") that will meet periodically through 1999 and 2000 is determining the substance of these elements and rules. ${ }^{15}$ Though a majority of states favored ICC authority over state national security decisions, an appropriate rubric was obtained regarding sovereign protection of national security information sought by the court. ${ }^{16}$ Finally, a number of provisions regarding general principles of criminal law were acceptably negotiated, including an appropriate definition of command responsibility ${ }^{17}$ and adequate criminal defenses such as a limited superior orders defense ${ }^{18}$ and defense of "mission essential property." 19

While many U.S. concerns were accommodated after hard-fought battles in Rome ${ }^{20}$ the most significant ones were not. As Ambassador David Scheffer, United States Ambassador-at-Large for War Crimes Issues and head of the U.S. delegation in Rome, said before the Senate Foreign Relations Committee

13. ICC Statute art. 5. Though the crime of aggression is listed in Article 5, the ICC's jurisdiction over that offense is predicated on the requirement that it is first defined in the statute through the amendment procedure, which could be initiated only at the first review conference seven years after entry into force.

14. See id. arts. $9,21 \& 22$.

15. The PrepCom was established in an annex to the final act of the U.N. Diplomatic Conference of Plenipotentiaries on the Establishment of an International Criminal Court in Rome, Italy, June 15July 17, 1998. Paragraphs 5 and 6 of Resolution F of the Final Act require the PrepCom to draft Rules of Procedure and Evidence and Elements of Crimes before June 30, 2000. Annex I, Resolutions adopted by the United Nations Diplomatic Conference of Plenipotentiaries on the Establishment of an International Criminal Court, U.N. Doc. A/CONF.183/10, Annex I, Resolution F, 5-6 (July 17, 1998) [hereinafter Resolution F]. The General Assembly requested the Secretary General to convene the PrepCom in G.A. Res. 53/105 (Dec. 8, 1998) and scheduled three meetings at the U.N. in New York. The first PrepCom meeting was held from February 16-26, 1999. Four additional three-week sessions resulted in completed Elements of Crimes and Rules of Evidence and Procedure documents on June 30, 2000. A sixth session took place in November and December of 2000 to work on financial regulations, a relationship agreement between the United Nations and the Court, and an agreement on privileges and immunities of the Court. Less frequent future sessions can be expected until entry-into-force.

16. ICC Statute art. 72.

17. Id. art. 28

18. Id. art. 33 .

19. Id. art. 31(1)(c).

20. Beside those mentioned above, Article 98 was negotiated to provide the possibility that bilateral agreements such as Status of Forces Agreements ("SOFAs") could be negotiated to preclude surrender of U.S. personnel to the ICC by a host state. "The Court may not proceed with a request for surrender which would require the requested State to act inconsistently with its obligations under international agreements ...." Id. art. 98(2). 
following conclusion of the Rome negotiations, "I regret to report that certain [U.S.] objectives were not achieved and therefore we could not support the draft that emerged." 21 While addressing the Sixth Committee of the United Nations several months later, Ambassador Scheffer was even more critical of the treaty that resulted from the Rome negotiations. Focusing on the jurisdiction provisions specifically, he said,

The Rome Treaty will become the single most effective brake on international and regional peacekeeping in the 21st century. [The] fundamental flaws in the Rome Treaty mean that the United States will not sign the present text of the treaty, nor is there any prospect of signing the existing text in the future. ${ }^{22}$

Where the treaty fails, it fails significantly. The ICC's jurisdictional regime not only is unsuccessful in providing adequate protection for U.S. troops and leadership if the United States were to become party to the treaty, ${ }^{23}$ but it also claims jurisdiction over non-party nationals. ${ }^{24}$ In addition, the final text of the treaty includes the crime of aggression as a prospective crime within the court's jurisdiction once it is defined-a result that both surprised and disappointed the U.S. delegation given the apparent intention of some states to define the crime without requiring a consistent Security Council determination. ${ }^{25}$ Finally, the United States has taken exception to several other statutory weaknesses such as the establishment of an "independent" prosecutor ${ }^{26}$ the "no reservations" clause, ${ }^{27}$ and an occupied territory offense that begs for politically motivated prosecutions. ${ }^{28}$

\section{IV}

\section{JURISDICTION}

Two aspects of the jurisdictional regime that emerged from the Rome conference call for two concomitant consequences. Because the jurisdictional regime does not adequately protect U.S. troops and commanders from politically motivated prosecutions, the United States cannot sign the treaty. More importantly, however, Ambassador Scheffer cautioned his counterparts in Rome that if they insisted on giving the court jurisdiction over non-party nationals outside the authority of the United Nations Security Council, the United States would

21. Hearing before the Subcomm. on Int'l Operations of the Comm. on Foreign Relations, 105th Cong., 2d Sess. (July 23, 1998)(testimony of Ambassador David Scheffer) [hereinafter SFRC Hearing].

22. Sixth Committee Statement, supra note 6.

23. See ICC Statute art 12(1).

24. See id. art. 12(2), (3). Since jurisdiction is a function of either territory or nationality, nonparty nationals accused of committing offenses extraterritorially can be subjected to the court's jurisdiction by virtue of the consent of the state on whose territory the offense is alleged to have occurred.

25. See id. $\operatorname{art} 5(1)(\mathrm{d})$.

26. See id. art. 15.

27. Id. art. 120 .

28. This offense was also drafted with a gloss on the Fourth Geneva Convention's traditional wording so that the offense proscribes transfers "directly or indirectly" of the occupying power's population. Compare Geneva Convention Relative to the Protection of Civilians in Time of War, Aug. 12, 1949, arts. 146-48, 6 U.S.T. 3516, 75 U.N.T.S. 287, with ICC Statute art. 8 (2)(b)(viii). 
be forced to oppose the court and its jurisdictional regime. Though the United States is currently engaged in efforts to reach agreement with the international community to allow a cooperative, supportive relationship between the ICC and the United States, the United States continues to be faced with the likelihood of having to oppose the ICC Treaty because of its assertion of jurisdiction over non-party nationals.

Regarding jurisdiction over individuals whose state of nationality is party to the treaty, the Rome negotiators settled on a regime that fell short of U.S. objectives to maintain certain jurisdictional control over its own forces. The statute grants the court "automatic" jurisdiction over the three categories of offenses for all states parties. ${ }^{29}$ Referrals initiating such jurisdiction can derive from any of three sources: the U.N. Security Council, a state party to the Statute, or the prosecutor acting in his or her independent capacity. ${ }^{30}$

The U.S. military has been much criticized for its stance on this critical aspect of the ICC Statute, but what the critics sometimes fail to recognize are the unique and vital national security responsibilities of the U.S. armed forces and the consequences of their front-line role in carrying out the nation's national security strategy. Though some bristle at a description of the United States as "the indispensable nation," ${ }^{11}$ it must be conceded that no other state regularly has nearly 200,000 troops outside its borders, either forward deployed or engaged in one of several operations designed to preserve international peace and security. To inhibit these forces as they seek to fill their crucial role is to take a step backwards in international peacemaking. "No peace without justice" was the mantra-like aphorism touted in Rome, but we must remember that likewise, there can be no justice without peace. When he addressed the Rome Diplomatic Conference, quoting then-U.S. Representative to the United Nations, Ambassador Bill Richardson said,

Many countries shoulder the burden of international security. The United States participates with other governments in military alliances and in the United Nations or other multi-national peacekeeping operations. Soldiers deployed far from home need to do their jobs without exposure to politicized proceedings. More generally, we are not here to create a court that exists to sit in judgment on national systems, to secondguess each action and intervene if it disagrees.

Unfortunately, inhibiting U.S. forces is exactly what some ICC proponents desire. When frustrated by an inability to influence U.S. foreign policy directly,

29. ICC Statute art. 12(1).

30. Id. art. 13. The concept of a proprio motu prosecutor was another distinct and significant concern of the United States that was not accommodated in the statute. The United States believed that the ICC prosecutor should not have authority to initiate investigations and prosecutions in the absence of a referral by either the Security Council or a state party.

31. The term, coined by Secretary of State Madeleine Albright, should here be understood in its narrow sense to refer to the United States as an indispensable participant in any major global problemsolving effort, not in the pejorative sense that would juxtapose other nations as dispensable. See Samuel P. Huntington, The Lonely Superpower, 78 ForEIGN AFF., Mar./Apr. 1999.

32. Remarks by William Richardson, U.S. Ambassador to the United Nations, in Rome, Italy, at the Opening Plenary Session of the United Nations Diplomatic Conference of Plenipotentiaries on the Establishment of an International Criminal Court (June 16, 1998)(on file with author). 
some may be inclined to impact it indirectly by targeting those who make and implement that policy. The military missions of our current era are markedly unlike the "traditional" cold-war scenarios of the past. Today, the U.S. military finds itself involved in a complex mixture of peacekeeping activities, humanitarian and disaster assistance missions, and counter-terrorism and counterproliferation missions, each unique and often carrying significant political "baggage" in an increasingly fractious world. Witness the situations in Kosovo and Iraq and the conflicts raging in Africa. In these circumstances, the military is often the instrument of first resort for policymakers. An ill-constituted ICC with the authority to make the final determination as to which cases will be investigated or come before it invites use of the court for political mischief. Those who would deny the possibility-even likelihood-of such ill-intended referrals overlook the natural trajectory of emotions stirred by the use of armed force. When the jus ad bellum basis for a particular military action is questioned, powerless victims of that application of force may seek redress by focusing on any jus in bello implementation issues raised by the actions of commanders and armed forces personnel. ${ }^{33}$

Late in the Rome negotiations, in an effort to bridge the gap between the United States and many of its friends and allies, the United States suggested a treaty regime in which states parties would accept the automatic jurisdiction of the court over the crime of genocide only, as had been recommended by the International Law Commission in 1994. As to the other core crimes, the United States attempted to facilitate participation in the treaty by proposing a ten-year transition period following entry into force of the treaty during which any state party could "opt-out" of the court's jurisdiction over war crimes and crimes against humanity. At the end of the ten-year opt-out period, several arrangements were proffered, including mechanisms whereby states could accept the automatic jurisdiction of the court over all of the core crimes, cease to be a party to the court (withdraw from the treaty), or extend the opt-out period. Even these modest suggestions were rejected (though a last-minute deal designed to break apart the five permanent members of the Security Council ac-

33. Recent events in Kosovo provide the quintessential example of this potential abuse. In 1999, there was increasing political pressure for International Criminal Tribunal for the former Yugoslavia ("ICTY") Prosecutor, Louise Arbour, to investigate "war crimes" committed by NATO forces and subject to ICTY jurisdiction. See, e.g., Jonathan M. Miller, International Law May Halt the Bombing, LA TIMES, May 11, 1999, at B-7 (arguing that bombing as a form of pressure is illegal and that President Clinton's plan to use bombing to increase pressure could yield a stronger ICTY case for war crimes like "wanton destruction of cities, towns or villages, or devastation not justified by military necessity"). A year later, Ms. Arbour's successor, Ms. Carla Del Ponte, succumbed to this political pressure and conducted an extensive inquiry into whether certain war crimes allegations and NATO's responses to those allegations should be "formally" investigated and/or prosecuted. Already, the preparation of NATO's response to the allegations has taken many months and hundreds of man-hours to prepare. See Charles Trueheart, War Crimes Court is Looking at NATO, WASH. POST, Dec. 29, 1999, at A20; Steven Erlanger, U.N. Tribunal Plays Down its Scrutiny of NATO Acts, N.Y. TIMES, Dec. 29,1999 , at A5. 
commodated French concerns by including a seven-year opt-out provision for war crimes). ${ }^{34}$

The ICC Statute creates automatic jurisdiction for states parties, even potentially withstanding a well-founded national decision not to prosecute. ${ }^{35}$ Though the United States would question the prudence of such a rubric, few would doubt a state's authority to consent to such an arrangement on behalf of its own citizens. Conversely, the statute's assertion of jurisdiction over nonparty nationals is significantly more inimical to fundamental principles of international law. In cases not referred by the Security Council, the treaty specifies that a precondition to the jurisdiction of the court is consent by either the state of territory where the crime was committed or the state of nationality of the alleged perpetrator (consent may be ad hoc or by virtue of joining the treaty). The United States sought an amendment to the text that would have required both of these countries to be parties to the treaty or, at minimum, that the consent of the state of nationality of the alleged perpetrator be obtained before the court could exercise jurisdiction. As a last resort, the United States recommended a provision that would discourage political manipulation of the court by excluding jurisdiction over non-party nationals when the conduct arose in the course of official acts of state. The United States was not successful, and the outcome threatens to undermine the credibility of the court. Again, quoting Ambassador Scheffer on this issue:

Our position is clear. Official actions of a non-state party state should not be subject to the court's jurisdiction if that country does not join the treaty, except by means of Security Council action under the U.N. Charter. Otherwise, the [treaty] ratification procedure would be meaningless for governments. Under such a theory, two governments could join together to create a criminal court and purport to extend its criminal jurisdiction over everyone, everywhere in the world. ${ }^{36}$

The authors of the jurisdictional regime would claim it to be an attempt to establish a "balance" between those who would desire a court with inappropriately expansive jurisdiction on the one hand, and those who would apparently weaken the court with too circumscribed a jurisdiction on the other. ${ }^{37}$ This sense of balance is misplaced, as it fails to give adequate recognition to the role of the Security Council or appropriate consideration to the court's role in existing international frameworks. The problem is that the drafters' paradigm

34. See ICC Statute art. 124 (authorizing a state, on becoming a party, to declare that it does not accept the court's jurisdiction for war crimes alleged to have been committed by its nationals for seven years).

35. If the ICC proves to act consistently with the apparent spirit of the Rome Treaty, the concept of complementarity would admittedly make the instance of a prosecution that overrides a state determination rare. Complementarity provisions allow ICC prosecution in contravention of a state's decision not to prosecute only if the decision is found by the court to result from the "unwillingness or inability of the State genuinely to prosecute." ICC Statute art. 17.1(b).

36. SFRC Hearing, supra note 21, at 13.

37. Keynote address by Mr. Philippe Kirsch for the Cornell International Law Journal symposium on the ICC (Mar. 5, 1998), printed in substantive part in Philippe Kirsch, Keynote Address, The International Criminal Court: Consensus and Debate on the International Adjudication of Genocide, Crimes Against Humanity, War Crimes, and Aggression, 32 CORNELl INT’L L. J. 437 (1999). 
does not recognize the value of a balance in its own right, but only the desirability of attracting support from as many states as possible. Thus, the drafters entertained proposals that created an independent court with as much authority as possible, while still attracting the support of as many states as possible. The able Chairman of the Committee of the Whole that drafted the Rome Statute, Canadian Phillipe Kirsch, opined that one of the purposes motivating the drafters of the ICC Statute was to break the U.N. Security Council's monopoly on international justice. ${ }^{38}$ Chairman Kirsch was correct. But this is neither a practical goal nor an especially noble one. The result is that there are significant gaps in global support for the treaty. "Breaking the monopoly" may translate into creating an additional stumbling block to badly needed proactive U.N. Security Council responses to international crises.

Ironically, while on one hand the court's jurisdiction is too independent and robust, inserted limitations went in the wrong direction. Most atrocities-and certainly such is the case in recent years-are committed internally. And most internal conflicts are between warring parties of the same nationality. Such internal crimes can easily escape the ICC's jurisdictional trigger of nationality or territory-based consent since the potentially relevant states are one and the same. Thus, the worst offenders of international humanitarian law can choose never to join the treaty and be fully insulated from its reach absent a Security Council referral. Recent events call our attention to Pol Pot and the vicious reign of the Khmer Rouge, the crimes of Saddam Hussein, and the Kosovo atrocities perpetuated by the regime of Slobodan Milosevic. To bring such rogue leaders or their mercenary consorts to justice often requires some form of intervention, perhaps based on Security Council authorization. However, any peacekeeper or peace enforcer sent to quash an ongoing humanitarian disaster, and perhaps to bring its perpetrators to justice, would not enjoy the same ICC immunity as the rogue state actors themselves. For instance, absent a Security Council referral, Milosevic would be immune from jurisdiction for any offense committed against his people, but NATO aircrews attempting to stop his forces from committing atrocities would not be. ${ }^{39}$

Thus, despite the attempt at a "balance," it might be argued that the Rome Treaty combines the worst of both worlds. Reaching the most egregious violations of fundamental human rights-those occurring in internal armed conflicts-still requires Security Council involvement (a feature opposed by those who favor a powerful, independent and autonomous court), but it does not re-

38. See id.

39. Article 12 of the ICC Statute is somewhat ambiguous in that it does not explicitly clarify whether a nonparty state's "consent" to jurisdiction based on territoriality would be attended by a consequent acceptance of jurisdiction for its own nationals. Some have begun discussing an interpretive fix to this provision to mitigate the perversity associated with a despot's ability to shield himself from jurisdiction while granting the ICC jurisdiction over foreign troops in his territory. A plain reading of Article 12 seems to allow one-sided acceptance of jurisdiction, but the language could be interpreted to involve some form of reciprocal or symmetric arrangement. However, it is unclear what temporal, geographical, and situational parameters would define that symmetric acceptance of jurisdiction. See ICC Statute art. 12. 
quire Security Council involvement to put even non-party peacekeepers at risk (a feature opposed by the United States). The treaty purports to establish an arrangement whereby U.S. armed forces operating overseas could conceivably be prosecuted by the ICC even if the United States has not agreed to be bound by the treaty. Not only is this contrary to fundamental principles of treaty law, ${ }^{40}$ it may inhibit the willingness of the United States to use its military to meet alliance objectives and participate in multinational operations, including interventions to save civilian lives. The treaty fails to provide desirable jurisdictional authority, while sacrificing important international law precepts in the process. In this way, the Rome Treaty undermines the achievement of the very principles and goals that purport to serve as its raison d'être.

\section{$\mathrm{V}$}

\section{THE ROME PROCESS}

The failings of the jurisdictional regime are inextricably linked to the unfortunate process that created it. Days before the conclusion of the Rome convention, there were few experienced diplomats who expected a treaty to be concluded. ${ }^{41}$ One cannot help but recognize the skills of those who managed to complete a text. Chairman Philippe Kirsch and a small team of bureau members drafted the treaty's most significant provisions literally in the middle of the night-hours before the conference was scheduled to end. Unfinished sections were taken from the drafting committee before its work was completed and pasted together to create the document. The treaty was then presented as a take-it-or-leave-it package and eventually adopted by vote after a final U.S. attempt at modification.

40. A thorough discussion of the legality of the ICC's jurisdictional regime under international law is beyond the scope of this article. The Vienna Convention on Treaties reaffirms the fundamental proposition of international law that those not party to a treaty are not bound by it. See Vienna Convention on the Law of Treaties, May 23, 1969, 1155 U.N.T.S. 331, reprinted in 8 I.L.M. 679. Of course, the twist in this instance is that the Rome Treaty does not purport to bind nonparty states directly, but it claims coercive enforcement power over nonparty states' citizenry. The question of legality becomes more complex when we note that the bases for jurisdiction, apart from Security Council referral, derive from the most widely accepted predicates for national jurisdiction: nationality and territory. States regularly establish jurisdiction over offenses that occur in their territory or are committed by their nationals. Likewise, several treaties, especially in the anti-terrorism field, establish "prosecute or extradite" requirements that concomitantly permit prosecution by a state with no direct territorial or nationality justification. However, these precedents do not dispositively resolve the question of whether states can "delegate" their jurisdictional authority to a third party, or, more importantly, whether an international institution has authority to accept jurisdiction so delegated. Closely related to this question is that of to what extent the offenses in question represent jus cogens or crimes of universal jurisdiction. If the argument ultimately relies on the prerequisite that the offense in question is a crime of universal jurisdiction, a significant discussion is then appropriate regarding the status of the numerous offenses in the ICC statute. See generally Address by Ambassador David Scheffer, International Criminal Court: The Challenge of Jurisdiction, Annual Meeting of the American Society of International Law (Mar. 26, 1999)(to be published in the proceedings of that annual meeting); Madeline Morris, High Crimes and Misconceptions: The ICC and Non-party States, 64 LAW \& CONTEMP. PROBS. 13 (Winter 2001).

41. Some delegates even left the conference early, expecting to return at a subsequent session. 
Besides the potentially untoward jurisdictional results discussed above regarding internal conflicts, this process resulted in several ironic, or perhaps even perverse, anomalies. For example, because of the extraordinary way deals were cut in the last hours of the negotiations, Article 124 creates a seven-year war crime "opt-out" for states parties. ${ }^{42}$ No such jurisdictional limitation is available to non-party nationals. Therefore, a state that becomes party to the treaty can opt out of war crimes and actually limit the court's jurisdiction over its own citizens while the nationals of non-party states are subject to the entirety of the court's subject matter jurisdiction. ${ }^{43}$ Non-party nationals are actually more vulnerable to the court's jurisdiction than nationals of states parties. Some have described this as an inducement to join the treaty. At best it is a thoughtless error; at worst it is an unabashed attempt to further isolate the United States in the final hours of the negotiation by drawing away one or more permanent members of the Security Council, which had otherwise held fairly consistent views on jurisdictional issues. ${ }^{44}$ Regardless of the motivation, it demonstrates the unprincipled nature of the jurisdictional regime.

Articles 11 and 121 are similarly perverse in their potential application. The temporal jurisdiction of the court, laid out in Article 11, limits jurisdiction to crimes committed after entry into force for that state. ${ }^{45}$ As with Article 124, the language of Article 11 is imprecisely drafted, ${ }^{46}$ but if the provision is interpreted as applying to individuals, then a state could theoretically shield an accused national by joining the statute before trial, thus immunizing the individual for all

42. Operative language from Article 124 reads, "A State, on becoming a party to the Statute, may declare that, for a period of seven years after the entry into force of this Statute for the State concerned, it does not accept the jurisdiction of the Court with respect to the category of crimes referred to in article 8 when a crime is alleged to have been committed by its nationals or on its territory."

43. An interesting interpretive issue arises as to whether the language of this provision applies to all cases against nationals of the relevant state, or only to state responsibilities under the treaty; that is, if the alleged offender's state of nationality is different from the state of territory where the offense occurred, and if the ICC's jurisdiction is based on the party status of the state on whose territory the offense occurs, and that state did not take advantage of the seven-year opt-out, then does a different state of nationality's opt-out shield the offender? The intent of the drafters was indeed to shield all nationals, regardless of the basis for jurisdiction. However, the language is not artfully drafted in this respect, and several treaty signatories have expressed an intent to interpret the exclusion in a more restrictive vein.

44. In fact, the United Kingdom joined the "like-minded" group (constituting the largest block of voting states) prior to the Rome Conference, but the other permanent members of the U.N. Security Council (the P-5) generally held positions similar to those of the United States on the most important issues throughout the conference. In the final days, the United Kingdom joined the other P-5 countries in their jurisdictional proposal that was ultimately rejected. At the end of the conference, France and Russia joined the majority after being offered the opt-out inducement.

45. Applicable language from Article 11 reads, "If a State becomes a Party to this Statute after its entry into force, the Court may exercise its jurisdiction only with respect to crimes committed after the entry into force of this Statute for that State ...." ICC Statute art. 11 (2).

46. The inartful wording of this provision, inserted long before any final jurisdictional regime was determined, leaves open the possibility that the provision applies to either the state and its obligations only, or to the nationals of that state as well. An informal polling of delegates at the Rome conference yielded both interpretations, though, as with Article 124, shielding individuals was clearly the intent of its drafters. 
conduct prior to the entry into force for that state. Non-party nationals do not enjoy such jurisdictional limitations.

Finally, Article 121 presents the clearest example of a jurisdictional anomaly since its language is unambiguously oriented toward individuals as opposed to states. Under paragraph five of that article, amendments to the list of crimes within the subject matter jurisdiction of the court are not applicable against nationals of states parties that fail to ratify the amendment. Therefore, states that join the treaty have the ability to shield their citizens from jurisdiction over all crimes not currently in the statute. There is no similar limitation, however, to the list of crimes that is potentially available for application against non-party nationals. Therefore, in theory, U.S. citizens could be made subject to the jurisdiction of the court for any number of currently unknown future offenses, even if the United States were not party to the treaty, but states parties could effectively shield their nationals.

Besides highlighting the unprincipled nature of the jurisdictional regime, this last example provides a good illustration of the unfortunate technical consequences of this last-minute package approach to treaty-making. With substantial portions of the treaty still unwritten on the last night of the five-week conference, the drafting committee was obviously unable to complete its work of rationalizing various constituent texts. Dozens of technical/administrative errors were discovered and corrected after the vote on the statute's text and after many had already signed the treaty. These corrections had (and have) varying degrees of substantive effect. ${ }^{47}$ In the case of Article 121, paragraph 5, both the version of the treaty adopted by the Rome Conference and the version initially distributed by the United Nations describes the amendment procedure for substantive offenses as applying to "Article 5" amendments. At the time the deal was made on Article 121's amendment provisions, the working drafts of the pertinent portions of the statute had all crimes listed in Article 5. Article 5 currently refers only to broad categories of crimes, which were further parsed in Articles 6,7, and 8. The "deal" language, however, was never adjusted. Thus, a technical reading of Article 121, paragraph 5 would presumably allow individuals to be prosecuted under crimes appended to Articles 6, 7, or 8, without regard to the status of ratification by the state of nationality. ${ }^{48}$ States parties could preclude jurisdiction only over a new "category" of crimes. The drafters of Article 121 clearly did not intend this result, and the most recent version of the

47. See Proposed Corrections to the Rome Statute of the International Criminal Court, U.N. Doc. C.N.502.1998, Treaties-3 (Annex).

48. Relevant language reads, "In respect of a State Party which has not accepted the amendment, the Court shall not exercise its jurisdiction regarding a crime covered by the amendment when committed by that State Party's nationals or on its territory." ICC Statute art. 121(5). Unlike Articles 11 and 124 , the language of this provision clearly precludes jurisdiction over any national of a non-ratifying state, regardless of the basis for jurisdiction. 
treaty text issued by the United Nations Secretariat includes an amendment that includes a reference to Articles 6, 7, and 8. ${ }^{49}$

Broader process-based concerns also attend the manner in which the treaty was adopted. Innis Claude, in his seminal work on the United Nations, gave significant weight to the various organizational dynamics subsumed within the institution..$^{50}$ Though the General Assembly operates on the simple democratic system of one vote per state, the U.N. Security Council acknowledges and reflects a Realpolitik that fit the post-World War II global community. While a discussion of these U.N. bodies is clearly beyond the purview of this article, few would contest the fact that neither the paradigm of the General Assembly nor that of the Security Council are the natural creations of unassailable logic. ${ }^{51}$ The balance reflected in these two institutions, however, coupled with the bureaucracy of the Secretariat, has served in some ways to structure the international order for the last fifty years. The ICC Statute and the process that created it threaten to undermine that order.

We see an incipient and unfortunate trend-given momentum by the Ottawa Landmine Convention-wherein states attempt to create "instant" customary international law. The putative authority for this customary status is simply the large number of signatories, making more important the fact that the Ottawa model does not establish the treaty text by consensus. A consensus approach to treaty-making best preserves the principles of consent and reciprocity among states, principles that have served as underpinnings of international law. Consensus-based negotiations marry the desire of some for democratic equivalence among states with the reality of inequalities of resources, population, and political and military power. Admittedly, there is a downside associated with the consensus rubric in that negotiations can be stymied by lack of agreement. A vote or the threat thereof can break a logjam, as it did in Ottawa and in Rome, but the result is ultimately reduced credibility and an inability to reflect legitimate and appropriate relative influence in de facto international lawmaking. The propriety of this method of international legislation is questionable and not deserving of U.S. support.

49. Article 121, para. 5 of U.N. Doc. A/CONF.183/9, released during the first year after July 17, 1998, still referred to "amendment[s] to article 5." The same provision in the current text reads, "Amendment[s] to articles 5, 6, 7 and 8 of this Statute."

50. See generally Inis L. Claude, Swords into Plowshares: The Problems AND PRocess OF INTERNATIONAL ORGANIZATION (1961).

51. Most legislative bodies today operate with authority and procedural rules deriving from some form of democratic principles. However, there is no "pure" democracy that fits every situation. The U.S. Congress is divided so as to recognize the legitimate representational interests of both states and individuals. Corporate charters usually reflect levels of financial commitment. In addition, the U.N. and other international organizations have their own schemes for attributing voting power. A discussion of these is beyond the scope of this paper, other than to point out the obvious: Different functional situations warrant different schemes. The authors of the U.N. Charter devised a scheme in which the international application of force does not require concurrence of all states, or even a majority of them. It does, however, require unanimity among five major powers. Conceding the fact that many in the community of nations view this particular scheme with disfavor, and accepting arguendo that a change is appropriate, it would seem obvious that the establishment of an international criminal court is not the ideal mechanism for effecting such a change. 
This "fast-track" approach is arguably more nefarious in the ICC context than it was in its Ottawa Convention sibling because the landmine ban never directly purported to establish direct legal authority over non-party states (though during the ICC negotiations, many claimed the Ottawa Convention had already established a customary norm due to the number of signatories alone). In the ICC context, however, the majority vote purports to establish coercive authority over the citizenry of the world. If a single treaty can in fact move us toward near-instant customary law status - a proposition that is doubtful at best-it should be a treaty adopted by consensus.

\section{VI}

\section{THE ICC'S INSTITUTIONAL ROLE}

One of the thorniest problems with the Rome Statute is not the substance of its authority, but the extent of that authority vis-à-vis other international institutions. Crassly stated, proponents of the court wanted as much authority given to judges as possible-even at the expense of, in fact, purposefully at the expense of, the traditional roles of states and other international institutions such as the Security Council.

Much of the conflict during ICC negotiations derived from the broad measure of displeasure in which the Security Council is viewed by many states. U.S. positions on the ICC treaty were generally consistent with the view that the ICC should be a court whose authority extends to individuals, but not states. Any court decision directed at the actions of sovereign state determinations would have only suasive authority, and the ICC's direct power would be carefully checked by other international structures such as the Security Council. By contrast, the court's most vocal proponents held the view that the more authority given to the ICC, the better.

The debate over the national security exception to state cooperation serves as a good example of the conflict of perspectives regarding the ICC's appropriate role internationally. For most of the five weeks in Rome, two fundamentally different proposals were on the table. Both allowed a state to refuse surrender of a document or other evidence for reasons of national security. However, one proposal allowed the court to assess the bona fides of a national security claim and ultimately to "order" the state to surrender material, without regard to the claim. The other (U.S.) proposal, authorized no such court "order" against a state, but instead ultimately allowed a referral of the matter to the assembly of states parties or the Security Council. While a successful result eventually was negotiated in the last hours of the conference, ${ }^{52}$ the debate

52. See ICC Statute art. 72. The United Kingdom had the competing proposal, which was very similar to the U.S. proposal except that it ultimately allowed the ICC to "order" surrender of classified documents that a state wanted to retain for national security reasons. The United Kingdom did not fear this provision because the threshold their proposal established for a court to rightly "order" surrender was so high that it would effectively preclude surrender. As a matter of principle, the U.S. proposal would not have allowed the court authority to "order" surrender since a state's national security 
clearly evinced a majority intent to have an international criminal court with coercive authority over states themselves. At one point, a delegation interceded with the statement that there appeared to be no room for compromise since the simple issue was whether or not the ICC should have authority over states themselves. That delegation's answer matched that of the majority of delegations that intervened-the ICC judiciary should have ultimate authority over any state.

The movement simply to create an international criminal court is itself a monumental task. The Rome Treaty, however, does more than simply create a court. It purports to transform fundamental international relations. Those who defend the legality of the ICC's jurisdictional regime claim that it does not violate international law because it is merely a delegation of uncontroverted sovereign state authority (that is, jurisdictional authority based on nationality and/or territory). Accepting, arguendo, the legality of that delegation, it does not necessarily follow that the ICC can accept that delegation. ${ }^{53}$ International law surrounding jurisdiction is grounded in the framework of a Westphalian system of state responsibility. Traditionally, responsibility for the exercise of jurisdiction has rested on the states. Through the ICC's regime, a state may delegate jurisdictional "authority." That authority exists, however, within a paradigm in which the same state must accept responsibility for the exercise of jurisdiction, and may ultimately be held accountable for it. Responsibility and accountability cannot be delegated.

Similarly, by claiming enforcement powers over non-party individuals, the ICC arguably redistributes enforcement authority currently reserved for the United Nations Security Council. This should have been ultra vires for the Rome conference. Since 1945, the Security Council has not fulfilled the most optimistic goals for the United Nations, and many see enforcement of international law as one of its failings. However, the existence of a shortcoming does not necessarily yield the conclusion that the ICC is the institution that should provide the remedy. Some see an inherent "unfairness" associated with the relative influence of the five permanent members of the Security Council. However, perceived unfairness does not necessarily militate in favor of shifting power to an independent international criminal court. "Fairness" has never been the talisman of international peace and security; the Security Council's structure is based on pragmatic concerns that simply cannot be ignored. An international criminal court should not be so independent as to encourage manipulation with the aim of influencing another state's foreign policy or national security interests. Coercive authority over the extraterritorial policies and activities of a state is the clear realm of the Security Council.

interests are inherently beyond the competence of the ICC's criminal judges. The U.S. position, in substance, ultimately prevailed, but only after its effects were camouflaged in the treaty's complex language.

53. See generally Morris, supra note 40. 
One aspect of the ICC treaty animates a great deal of the colloquy on how the United States should respond to it, and that is the complementarity regime. The preamble to the Rome Statute states that "the International Criminal Court established under this statute shall be complementary to national criminal jurisdictions. ${ }^{" 54}$ Articles 17-19 give life to this principle and, indeed, provide a helpful standard recommending judicial restraint. Under the formula of Article 17, cases are inadmissible when they are being or have been investigated or prosecuted by a relevant state. However, the statute also gives the ICC authority to admit the case if the investigation, prosecution, or related decision is deemed to result from an "unwillingness or inability of the [s]tate genuinely to prosecute." $"$ All of the checks and balances related to complementarity are still fatally inadequate because they are entirely self-judged and applied by the ICC.

Many argue that the United States can always be expected to investigate and prosecute its own and need not fear an ICC. This argument is usually accompanied by acclaim for the U.S. military's well-conceived law of war program $^{56}$ and military justice system. ${ }^{57}$ Indeed, it is virtually certain that every legitimate claim involving egregious violations of the law of war will result in some form of internal investigation and/or prosecution. However, it is not actual violations, legitimately investigated and prosecuted, with which the United States is concerned. The concern is use of the court as a tool for influencing U.S. foreign policy by holding at risk those who implement that policy. For example, Libya recently opened legal proceedings against various members of the Reagan Administration, including military officers, for the 1986 air raids on Tripoli and Benghazi, charging them with premeditated murder. ${ }^{58}$ Certainly, the United States does not view these factual circumstances as warranting a criminal investigation for war crimes, but the potential impact on foreign policy if such allegations were given currency is manifest.

Promoters of the current statute blithely credit the future judiciary with apolitical self-restraint that will pose no threat to U.S. foreign policy or those who implement it. Additional protections like that of the pretrial chamber are said to take the risk of wayward proceedings to infinitesimal levels. While there is every reason to believe the ICC will attract only the most qualified servants of the rule of law, Americans, for good reason, are not culturally disposed toward such "trust" of an institution. Founders of the United States established a carefully structured separation of powers that is not as evident in other democratic governments. Though coined by a British Lord, the maxim that power tends to

54. ICC Preamble (10).

55. Id. art. $17(1)(\mathrm{a})(\mathrm{b})$.

56. See generally DePARTMENT OF DEFEnSE DiRECTIVE 5100.77, DoD LAW OF WAR PROGRAM (Dec. 9, 1998)(detailing implementation of law of war program throughout Defense Department).

57. See generally MANUAL FOR COURTS-MARTIAL, UniTED STATES (1984)(executive order regulating implementation of the Uniform Code of Military Justice).

58. See Libya charges Reagan officials with "premeditated murder," WASH.TIMES, Apr.14, 1998, at 13; see also supra note 33 (discussing Kosovo example). 
$\operatorname{corrupt}^{59}$ perhaps enjoys greater recognition among Americans. Despite the ICC treaty's incorporation of several internal checks and balances (largely at U.S. insistence), the prosecutor does not answer to any executive authority and the court is not subject to balances provided by a separate legislature. In the case of non-parties, the Court's rulings regard individuals to whom it is not in any way accountable.

It is recognized that a consequence of the ICC Statute is to dilute the veto power of the five permanent members of the Security Council. Though some praise this circumstance as freeing the court of political fetters, it also frees the court from a carefully devised political accountability. Courts tend to arrogate power to themselves, and the argument that an international institution will not do anything unreasonable because of self-restraint is simply untenable. Complementarity is the right principle, but the ICC's structure is not one that adequately safeguards it. As the longest standing constitutional republic in the world, the United States should think twice about abandoning the principles that have given it that credential.

\section{VII}

\section{THE WAY AHEAD}

After deciding not to join the Ottawa landmine ban in September 1997, the Administration issued statements with carefully worded remarks pointing to U.S.-specific circumstances as the reason it could not join the treaty. While the United States' conciliatory posture after the Ottawa negotiations concluded in Oslo was "diplomatic," it had the unfortunate side effect of perpetuating the myth that the problem resided with the U.S. armed forces that refused to support the treaty. The United States thereby conceded the moral high ground to treaty proponents when it is the Ottawa Convention itself and the attendant negotiating process that is deficient. Conversely, with respect to the ICC, the United States has been clear that the deficiency lies with the Rome Treaty and the path taken to create it. The United States' support for the ICC should be dependent on whether post-Rome negotiations yield acceptable accommodations of U.S. concerns. At the July 1998 Senate Foreign Relations Committee Hearing on the ICC, Ambassador Scheffer concluded that "the Administration hopes that in the years ahead, other governments will recognize the benefits of potential American participation in the Rome Treaty and correct the flawed provisions in the treaty." 60

What will it take for the United States to "embrace" the ICC? Adjustments must be made to the treaty's jurisdictional effects. In order to obtain a peaceful coexistence with the court, arrangements conferring jurisdiction over non-party nationals should be amended to require either Security Council or state of na-

59. Letter from Lord Acton to Lord Creighton (Apr. 5, 1887).

60. SFRC Hearing, supra note 21, at 15. 
tionality consent for any offenses involving officially acknowledged state acts. ${ }^{61}$ Alternatively, a more robust concept of complementarity could accomplish the same end. In order for the United States to consider signing the treaty, the jurisdictional regime should be recast to protect U.S. officials and armed forces members from politically motivated investigation and prosecution.

The specifics of adequate solutions are beyond the purview of this article, but various conceptual avenues seem plausible. A complementarity-based solution, in which the ICC is not independently vested with authority to overturn a state's complementarity determinations, would preserve appropriate tenets of interstate comity. A strengthened opt-out regime would accommodate those who want to obtain the broadest participation while allowing the court to "prove" itself over time. An "official acts" exclusion could properly focus the court's attention on individual offenses while raising the political stakes for those leaders who could then shield their crimes only by admitting them to be officially sanctioned. ${ }^{2}$

Prospects for an accommodation of U.S. jurisdictional concerns are mixed, and for some states, form is as important as substance. Accommodations along any one of the lines mentioned above would have to take account of the delicate sensitivities associated with doing something that appears to alter the statute itself. In November of 1998, the Sixth Committee of the United Nations submitted a resolution relating to the ICC, which the General Assembly adopted by consensus in December. While the principal aim of the resolution is to establish the Preparatory Commission to foster continued work and support for the ICC treaty text adopted in Rome, in a concession to U.S. urgings, the resolution also calls on the Preparatory Commission to "discuss ways to enhance the effectiveness and acceptance of the court." ${ }^{93}$ Ambassador Scheffer has been energetically exploring potential accommodations at each Preparatory Commission session and in bilateral meetings during the intersessional periods. The last chapter has yet to be written.

\section{VIII}

\section{CONCLUSION}

The United States remains committed to the furthering of international justice and accountability. The United States' support for the Yugoslavia and Rwanda War Crimes tribunals more than proves this point. What the United States cannot support is an international court that fails to recognize its unique responsibilities in the world when issues of international peace and security are

61. One could argue that this formula preserves the international law standard of consent as the basis for all normative restrictions. Consent would be either direct and specific, through an ad hoc decision, general, through acceding to the treaty, or implied, through agreement with the U.N. Charter scheme that serves as the basis for Security Council authority.

62. For a brief discussion of an "official acts" exclusion, see Theodor Meron, The Court We Want, WASH. POST, Oct. 13, 1998, at A15.

63. See G.A. Res. 53/105 (Dec. 8, 1998). 
involved. As Ambassador Scheffer recently wrote, the United States is "called upon to act, sometimes at great risk, far more than any other nation. That fact is sometimes hard for others to appreciate when [they], so hopeful for the infallibility of a future international court, lose sight of other realities in the international system."

It is important to remember that this is not merely a U.S. problem or an example of American exceptionalism; it is the statute that needs to be strengthened. The creation of any judicial system requires a delicate balance between protecting individual rights and furthering the interests of justice, between maximizing the ability to convict the criminal and protecting the human rights of the innocent. Likewise, the creation of any governmental authority involves balancing the powers with which it is imbued and the restraints that keep it accountable. These balances become both more complex and more delicate as we enter the world of customary international law, international relations, and international institutions with no clear authority to which they are accountable.

All of the U.S. proposals related to an international criminal court have been grounded in a thoughtful attempt to incorporate appropriate checks and balances into the ICC Statute. On the micro level, U.S. proposals, such as the one for elements of crimes, reflect recognition of the necessary balance between bringing an individual to justice and protecting that individual's rights and the integrity of the system. From a macro perspective, U.S. jurisdictional proposals reflect an attempt to balance necessary judicial authority on one side, and preservation of state sovereignty and current structures that promote international peace and security on the other.

Unfortunately, many with the best intentions have hastily joined a movement in which the delicacy of these balances has not been adequately acknowledged. International humanitarian law is simply seen as either "progressing" or "regressing." Safeguards built in by the United States are viewed as "concessions" that "raise the bar" for the prosecutor, and the only "balance" sought is one between the inherent strength of the court, and widespread support for it.

A more deliberate and sophisticated review is required. Recognition of the need for appropriate checks and balances is really an acknowledgment that the rule of law itself must be preeminent. Both the "no peace without justice" mantra and its antithesis are incomplete. There can be neither peace nor justice unless the rule of law itself has been firmly established, and the voice of a simple majority of states cannot rightly claim to have established that rule of law. The United States' participation is not only needed for practical reasons, but also to bolster the court's moral authority, and eventually its universal acceptance.

The establishment of an international criminal court is a noble undertaking described by some as fulfilling a vision of moving the world from a "culture of 
impunity" to a "culture of accountability." It is, in fact, perhaps one of the most important undertakings of the last several decades, making the unfortunate circumstances that attended its genesis that much more disturbing. Cobbling together text to establish such a court on the penultimate day of a diplomatic conference, in the face of direct and clear opposition by one of the free world's leading powers, is not an auspicious beginning for the "culture of accountability." As it was with Mark Twain, to report the ICC's death would be premature, but so is the fanfare regarding its birth. More work needs to be done to give the court the credibility, the longevity, and, ultimately, the authority it deserves. The changes sought by the United States should be implemented not just because U.S. participation is key to an effective, functioning court, but because enacting them promotes the rule of law and is therefore the right thing to do.

64. The Chairman of the Committee of the Whole at the Rome Conference, Philippe Kirsch, has so described the vision captured by the ICC Statute. See Keynote Address by Mr. Phillipe Kirsch, supra note 37. 